\title{
42. DATA REPORT: GEOCHEMICAL RESULTS FROM WIRELINE LOGS AT SITES 752, 754, AND $758^{1}$
}

\author{
Elizabeth Lewis Pratson, ${ }^{2}$ Craig R. Wilkinson, ${ }^{2}$ and Cristina Broglia ${ }^{2}$
}

\begin{abstract}
Geochemical well logs were obtained at Sites 752, 754, and 758 of Leg 121 on Broken Ridge and Ninetyeast Ridge. The shipboard log measurements have been processed to correct for borehole size changes, drilling fluid conditions, logging speed variations, and to calculate the naturally radioactive elements and dry weight percentages of oxides in the formation. The final geochemical logs are discussed with lithologic core descriptions and help define the major lithologic changes.
\end{abstract}

\section{INTRODUCTION}

Leg 121 of the Ocean Drilling Program (ODP) took place in the eastern Indian Ocean for the purpose of unraveling the tectonic and stratigraphic history of Broken Ridge and Ninetyeast Ridge. The former is a conjugate rift fragment, the later a paleo-hotspot trace (Peirce, Weissel, et al., 1989). These two features record the tectonic and depositional history of the area and, because of their shallow nature, represent an ideal setting for drilling and logging.

Logging was carried out at three of the seven sites drilled during Leg 121: Sites 752 and 754, located on Broken Ridge, and Site 758, located on Ninetyeast Ridge. Although the original logging plans called for a complete suite of electrical, acoustic, and nuclear logs at each site, these plans were revised due to adverse hole conditions. A complete string of nuclear geochemical logs was, however, run at each of the three logged sites. Geochemical log measurements are useful when deriving the weight fraction of the major oxides present in the formation.

This paper will discuss the borehole conditions of each site logged with the geochemical tool, the basic principles and modes of operation of the geochemical tool, and the processing techniques. Finally, the processed geochemical logs will be presented and compared to lithologic core descriptions.

\section{DATA ACQUISITION}

In preparation for logging, a polymer gel mud sweep was pumped in each site and a full wiper trip was made before releasing the bit. The holes were then displaced with seawater and $\mathrm{KCl}$ ( $8 \%$ by volume). $\mathrm{KCl}$ is added to the hole to stabilize freshwater clays, which often swell and form bridges in the hole. Even though weather conditions were favorable, borehole instabilities (bridge formation in Hole 752B, chert/gravel layer in Hole 754B, and sediment accumulation at the bottom of the borehole in Hole $758 \mathrm{~A}$ ) prevented logging of the full length of borehole.

In Hole 752B two tool strings, the seismic-stratigraphic and the lithodensity, were run before geochemical logging was attempted. Bridge formation caused the temporary loss of the seismic-stratigraphic tool, and the lithodensity tool became temporarily stuck at 339 mbsf. To ensure that the geochemical logging tool would not become lost or stuck, pipe was run in the hole to knock out bridges, followed by a mud sweep. The hole

\footnotetext{
'Weissel, J., Peirce, J., Taylor, E., Alt, J., et al., 1991. Proc. ODP, Sci. Results, 121: College Station, TX (Ocean Drilling Program).

${ }^{2}$ Lamont-Doherty Geological Observatory of Columbia University, Palisades, NY 10964, U.S.A.
}

was then logged with the geochemical tool from 395 mbsf up to the bottom of the pipe at $127 \mathrm{mbsf}$.

Hole 754B contained several zones of chert and gravel, which made both drilling and core recovery difficult. To ensure the recovery of the geochemical logging tool string, the pipe was kept at $160 \mathrm{mbsf}$ across an unstable gravel zone. One complete pass was run in this hole from 318 mbsf to the mud line along with a repeat pass through pipe. The seismic-stratigraphic tool string was run next; however, as a result of pipe sticking, logging operations were stopped early.

Hole $758 \mathrm{~A}$ was logged following hole-reentry using a minicone. The seismic-stratigraphic combination was run first; a bridge at 405 mbsf, however, prevented logging in the lower portion of the well. This run was followed by an open-hole logging run with the geochemical logging tool string, from 382 mbsf up to the bottom of the drill pipe at $42 \mathrm{mbsf}$.

\section{GEOCHEMICAL TOOL STRING}

The geochemical logging tool (GLT) string consists of four separate logging tools: the natural gamma-ray tool (NGT), the compensated neutron tool (CNT), the aluminum activation clay tool (AACT), and the gamma-ray spectroscopy tool (GST; Fig. 1). (GLT, NGT, CNT, AACT, and GST are trademarks of Schlumberger.) The NGT is located at the top of the tool string so that it can measure the naturally occurring radionuclides-thorium, uranium, and potassium - before the formation is activated by the nuclear sources mounted on other following tools. The compensated neutron tool located below the NGT carries a low-energy neutron californium $\left(\mathrm{Cf}^{252}\right)$ source which activates the aluminum atoms in the formation. The aluminum activation clay tool is a modified NGT which follows the $\mathrm{Cf}^{252}$ source, measuring the activation gamma rays in the formation. By combining this measurement with the previous NGT measurement to subtract background radiation, a reading of formation $\mathrm{Al}$ is obtained (Scott and Smith, 1973). Finally, the gamma-ray spectroscopy tool, located at the bottom of the string, uses a pulsed neutron generator to induce capture reactions in the formation and a detector to measure the spectrum of captured gamma rays. Because each of the elements in the formation is characterized by a unique spectral signature, it is possible to derive the contribution (or yield) of the major elements silicon ( $\mathrm{Si})$, iron $(\mathrm{Fe})$, calcium $(\mathrm{Ca})$, titanium $(\mathrm{Ti})$, sulfur $(\mathrm{S})$, gadolinium $(\mathrm{Gd})$, and potassium $(\mathrm{K})$ to the measured spectrum, and in turn to estimate their abundance in the formation. The gamma-ray spectroscopy tool also measures hydrogen $(\mathrm{H})$ and chlorine $(\mathrm{Cl})$, but these elements are not used in determining the rock geochemistry. 


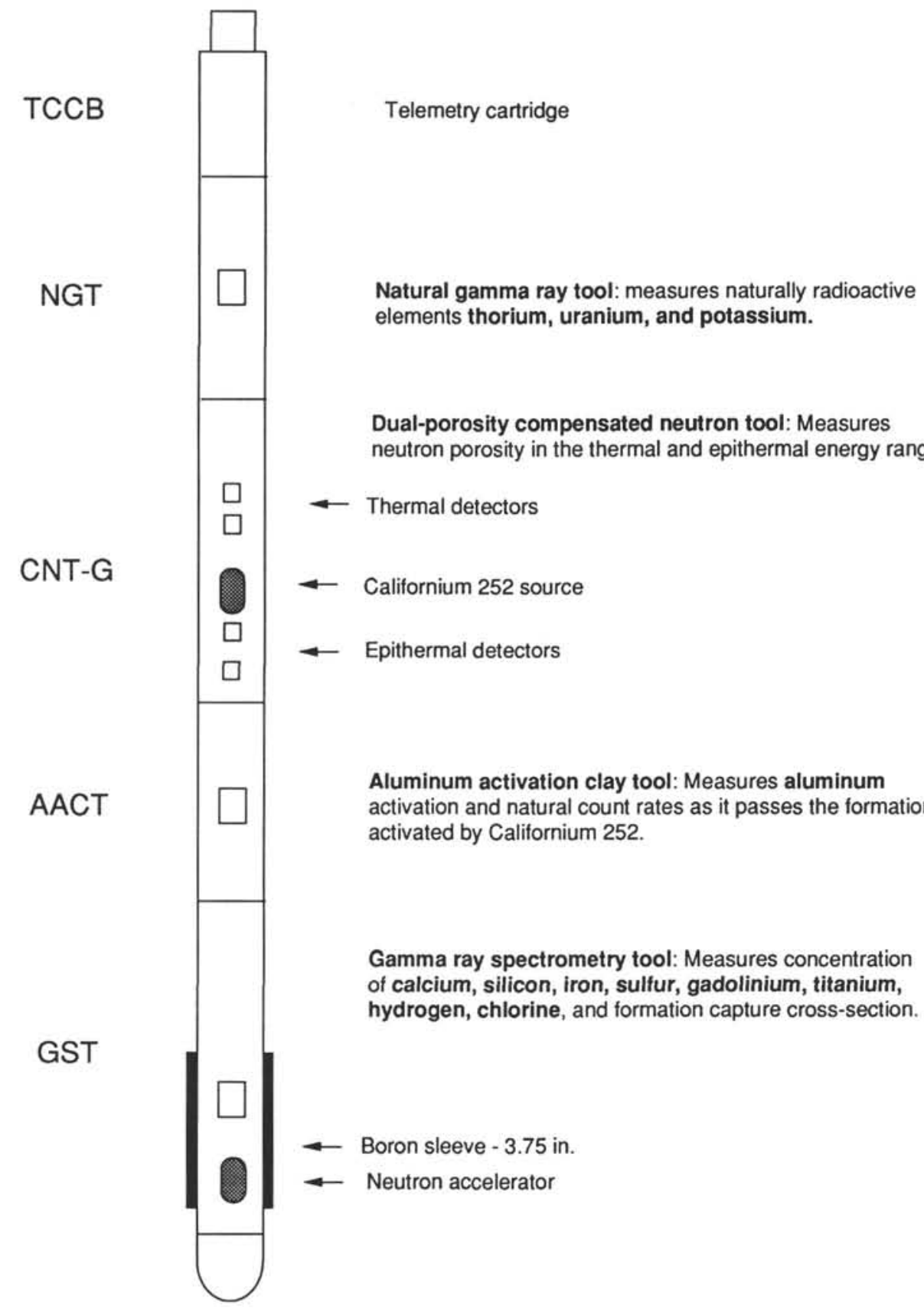

Figure 1. Schematic drawing of the geochemical tool string and the elements that each tool measures. The boron sleeve was not present on the tool during Leg 121 . The geochemical tool has since been modified to include the boron sleeve to mask out iron readings from the tool.

The only major elements not measured by the geochemical tool string are magnesium $(\mathrm{Mg})$ and sodium $(\mathrm{Na})$. The neutron-capture cross-sections of these elements are too small to be detected by the gamma-ray spectroscopy tool. An estimate of their abundances can be made using the photoelectric factor, a measurement obtained from the lithodensity tool. This calculation was done in Hole 752 only, as this was the only well in which the lithodensity tool was run.

\section{PROCESSING OF GEOCHEMICAL LOG DATA}

The well log data from the Schlumberger tools are transmitted digitally up a wireline, and are recorded and processed on the JOIDES Resolution in the Schlumberger Computer Service Unit (CSU). The results from the CSU are made available as "field $\log s$ " for initial interpretation while at sea. Subsequent reprocessing is necessary to further correct the data for effects of logging 
conditions, including hole size changes, fluids added to the well, and logging speed. Processing of the spectrometry data is required to transform the relative elemental yields into oxide weight fractions.

The processing is done using a set of $\log$ interpretation programs written by Schlumberger. The processing steps are summarized below:

\section{Reconstruction of 10 relative elemental yields from recorded spectral data.}

The first program compares the measured spectra from the geochemical spectroscopy tool with a series of standard spectra to determine the relative contribution (or yield) of each element using a least squares method. Whereas only six elemental standards are used to produce the yields at sea, during processing at Lamont-Doherty three additional standards ( $\mathrm{Ti}, \mathrm{Gd}, \mathrm{K}$ ) are utilized. Although these three elements are often at low concentrations in the formation, they can make a large contribution to the measured spectra because they have large neutron-capture crosssections. The capture cross-section of Gd, for instance, is 49,000 barns; that of $\mathrm{Si}$ is 0.16 barns (Hertzog et al., 1987). Gd, therefore, although occurring in very small abundances in the formation, is an important element to include when trying to obtain a best fit between the measured and the calculated spectrum. This process gives $\mathrm{Si}, \mathrm{Ca}, \mathrm{Fe}, \mathrm{Ti}, \mathrm{Gd}, \mathrm{S}, \mathrm{H}, \mathrm{Cl}$, and $\mathrm{K}$ as final yields. Before any further manipulation of the yields is done, a 10-point smoothing filter is applied to reduce the amplitude of the statistical noise in the data. The iron yield also is corrected for effects caused by the iron in the tool and drill pipe by applying an appropriate offset.

\section{Calculation of total radioactivity and $T h, U$, and $K$ concentration.}

The second routine estimates the total gamma radiation, along with the concentrations of $\mathrm{Th}, \mathrm{U}$, and $\mathrm{K}$, by using the counts in five spectral windows from the natural gamma-ray tool (Lock and Hoyer, 1971). Again, the process resembles the one done at sea. On shore, however, a caliper curve is used to correct for borehole size. A second difference lies in the complexity of filtering. Because statistical errors in the logs often create erroneous negative readings and anti-correlations (especially between Th and U), a Kalman-type filter (Ruckenbusch, 1983) is applied to reduce these effects. A slightly more sophisticated version of the Kalman filter is available for land-based processing. The processing done on land also allows for an estimate of potassium from the drilling mud in the hole. This is particularly useful in the Ocean Drilling Program where $\mathrm{KCl}$ is often added to the hole; yet it may be so diluted by the time it reaches the hole that any correction for its addition can cause $\mathrm{K}$ to be negative. The outputs of this program are: $\mathrm{K}$ (wet weight percent), $\mathrm{U}$ (ppm), and Th (ppm), and total and computed gamma-ray curves $(\mathrm{Th}+\mathrm{U})$.

\section{Calculation of Al concentration.}

The next routine calculates an aluminum curve by analyzing four energy windows from the aluminum activation clay tool while simultaneously correcting for borehole fluid neutroncapture cross-section, formation neutron-capture cross-section, formation slowing-down length, and borehole size. Resistivityderived porosity (Holes 752B, 758A) and neutron porosity (Hole 754B), along with resistivity-derived density (Holes 752B, 758A) and density from the lithodensity tool (Hole 754B), were input to convert aluminum and potassium to dry weight percentages (wt\%). A correction is also made for silicon in the formation, which can become activated by the $\mathrm{Cf}^{252}$ source, causing a reaction that produces the aluminum isotope $\mathrm{Al}^{28}$. Because this silicon reaction creates a direct interference with the aluminum calculation (Hertzog et al., 1987), the program uses the silicon yield from the gamma-ray spectrometry tool to determine the silicon background correction. The program outputs dry wt\% of $\mathrm{Al}$ and $\mathrm{K}$, which are used in the normalization process for calculating the remaining elements.

\section{Photoelectric factor corrections.}

A photoelectric factor (PEF) curve is used in the calculation of $\mathrm{MgO}+\mathrm{Na}_{2} \mathrm{O}$. Before the PEF curve can be used, however, it must be corrected for tool standoff from the borehole wall and converted to a dry wt\% reading. This was done in the case of Hole $752 \mathrm{~B}$, the only well in which a lithodensity tool string (which gives PEF) was run.

\section{Normalization of $A l$ and $K$ with yields for the calculation of elemental weight fractions and with calculation of $\mathrm{Mg}+\mathrm{Na}$.}

The next routine takes the dry $\mathrm{wt} \%$ of $\mathrm{Al}$ and $\mathrm{K}$ and normalizes them with the reconstructed yields to obtain dry wt\% of the elements using the relationship:

$$
W t_{i}=F Y_{i} / S_{i}
$$

where $W t_{i}$ is the absolute elemental concentration, $F$ is the normalization factor, $Y_{i}$ is the relative elemental yield, and $S_{i}$ is the tool spectral sensitivity. The normalization factor, $F$, is a calibration factor determined at each depth to account for the presence of carbon (C) and oxygen $(\mathrm{O})$ associated with each element. Because the sum of oxides in a rock is $100 \%, F$ is given by

$$
F\left(\sum X_{i} Y_{i} / S_{i}\right)+X_{\mathrm{K}} W t_{\mathrm{K}}+X_{\mathrm{Al}} W t_{\mathrm{Al}}=100
$$

where $X_{i}$ is the dry wt\% of oxide from element $i, Y_{i}$ is the fraction of spectra attributed to element $i, S_{i}$ is the sensitivity factor of element $i$, $X_{\mathrm{K}}$ is the dry $w t \%$ of oxide of $\mathrm{K}$ divided by the dry $w t \% \mathrm{~K}, W t_{\mathrm{K}}$ is the dry $w t \%$ of $\mathrm{K}, X_{\mathrm{Al}}$ is the dry $\mathrm{wt} \%$ of $\mathrm{Al}$ oxide divided by the dry wt $\%$ $\mathrm{Al}$, and $W t_{\mathrm{Al}}$ is the dry wt\% Al. The sensitivity factor, $S_{i}$, is a tool constant, measured in the laboratory, which depends on the capture cross section of each element measured by the geochemical tool (Hertzog et al., 1987).

The routine next calculates the sum $(\mathrm{Mg}+\mathrm{Na})$ when the PEF curve from the lithodensity tool string is present. When these elements occur in significant quantities, they can be estimated by comparing the measured photoelectric factor (PEF) from the lithodensity tool with a calculated PEF curve. Because the PEF of each element is known, a photoelectric factor curve can be calculated, assuming no $\mathrm{Mg}$ and $\mathrm{Na}$ in the formation. The difference between this calculated PEF curve and the measured PEF log is assumed to be due to $\mathrm{Mg}$ and $\mathrm{Na}$ (Hertzog et al, 1987).

\section{Calculation of oxide percentages.}

The final routine simply multiplies the percentage of each element by the oxide or carbonate factor associated with each element. These factors are listed in Table 1.

Table 1. Factors used to convert elements to oxides and normalize elements to $100 \%$.

\begin{tabular}{lcc}
\hline Element & Oxide/carbonate & Conversion factor \\
\hline $\mathrm{Si}$ & $\mathrm{SiO}_{2}$ & 2.139 \\
$\mathrm{Ca}$ & $\mathrm{CaCO}_{3}$ & 2.497 \\
$\mathrm{Fe}$ & $\mathrm{FeO}^{*}$ & 1.358 \\
$\mathrm{~K}$ & $\mathrm{~K}_{2} \mathrm{O}$ & 1.205 \\
$\mathrm{Ti}$ & $\mathrm{TiO}_{2}$ & 1.668 \\
$\mathrm{Al}$ & $\mathrm{Al}_{2} \mathrm{O}_{3}$ & 1.899 \\
$\mathrm{Mg}$ & $\mathrm{MgO}^{2}$ & 1.658 \\
\hline
\end{tabular}

Note: $\mathrm{FeO}^{*}$ denotes total iron. 

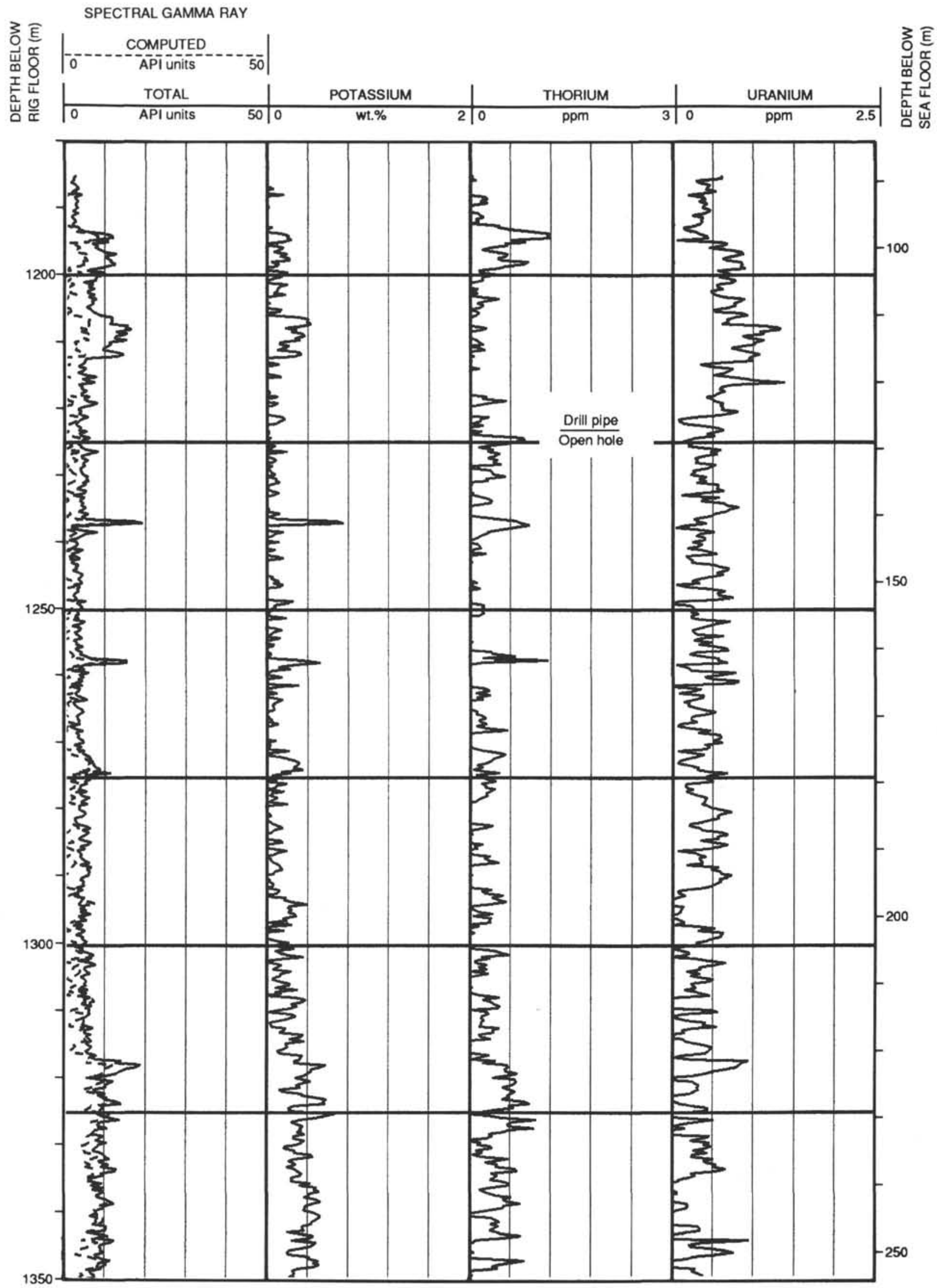

Figure 2. Processed natural gamma-ray curves from Hole 752B. 

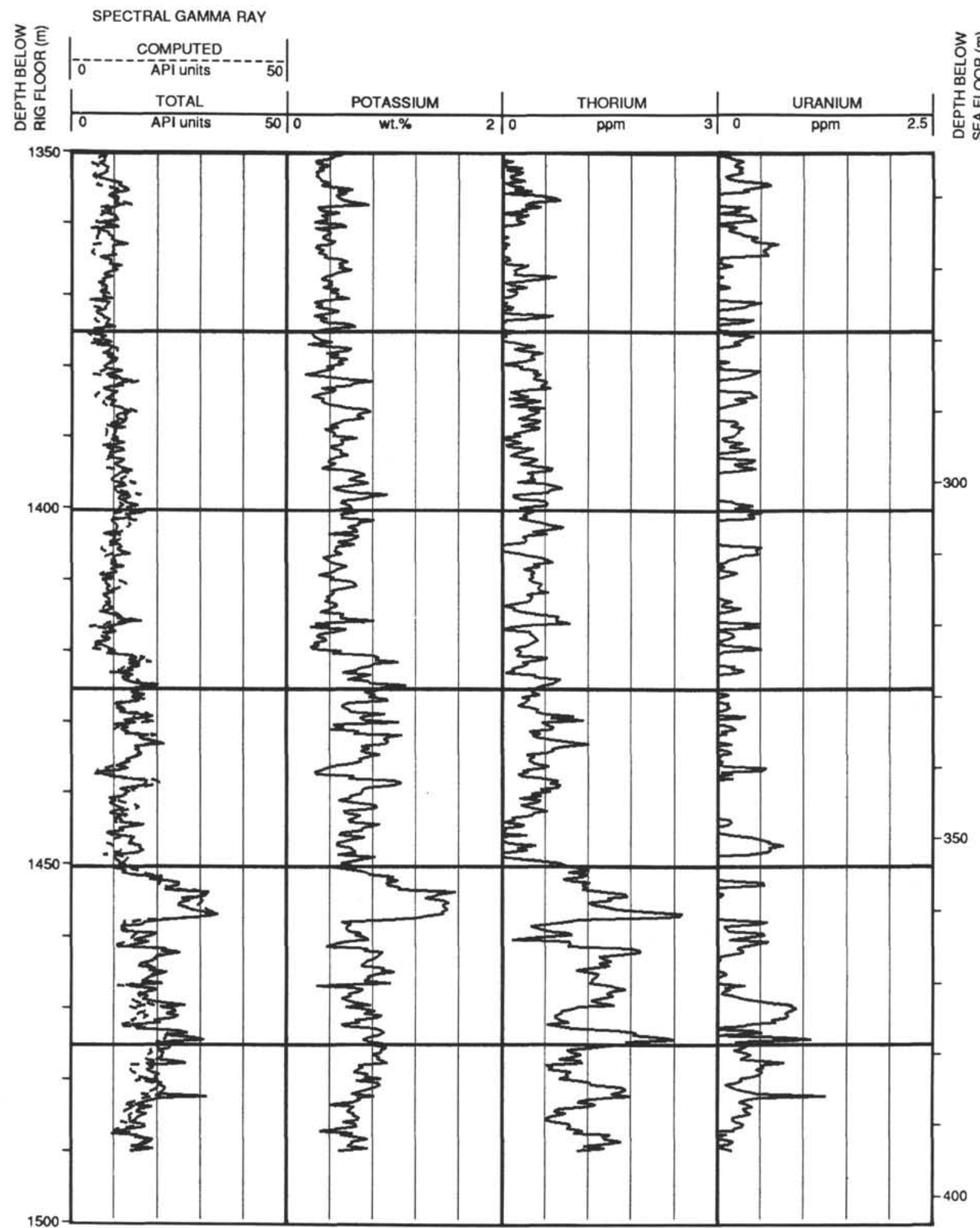

Figure 2 (continued). 


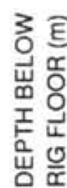

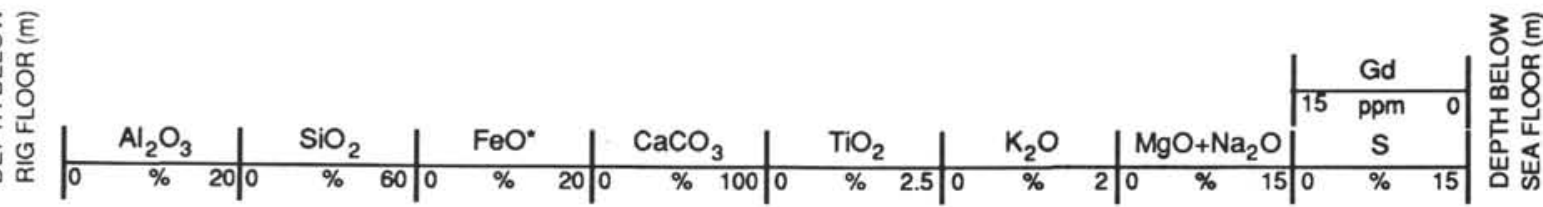

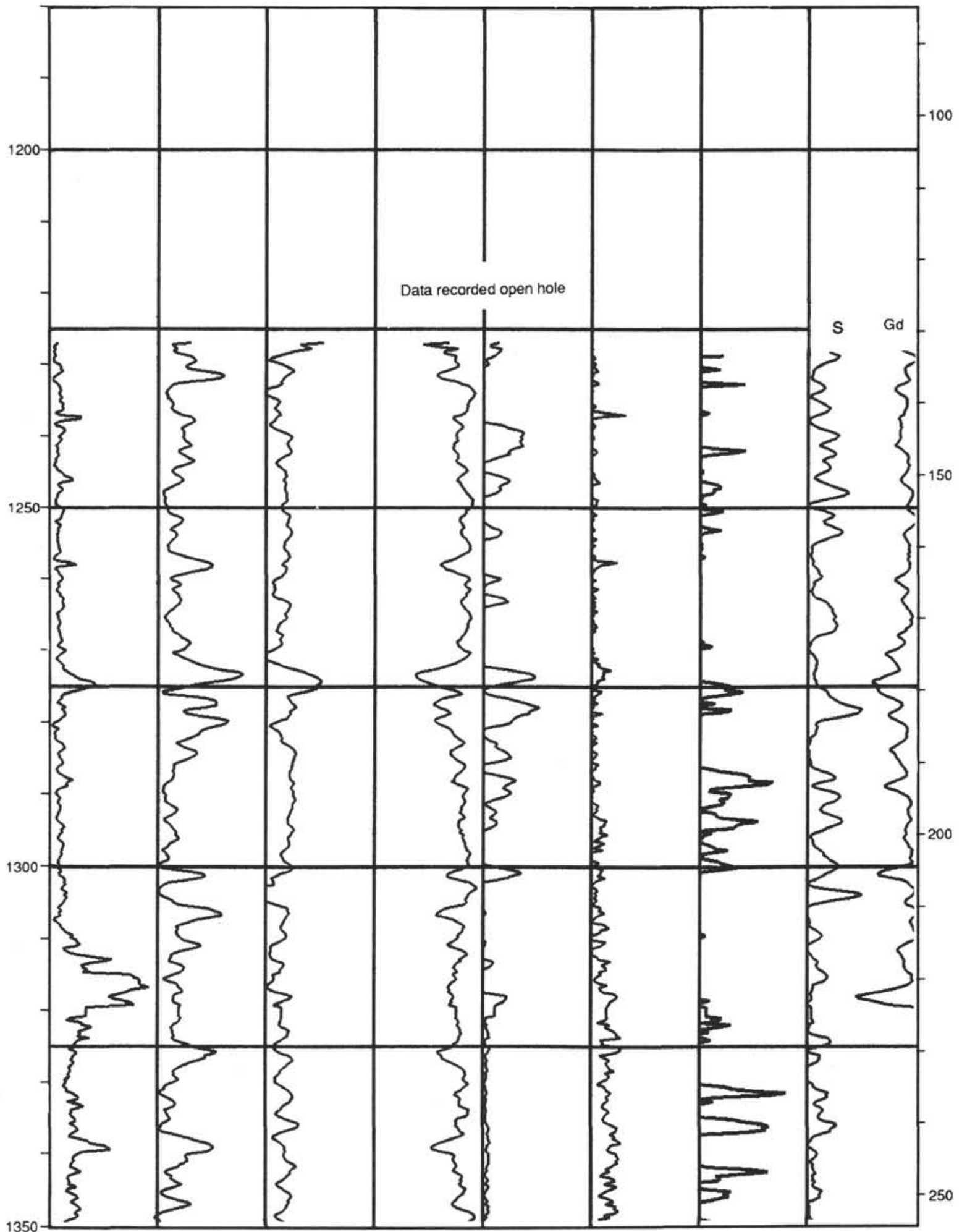

Figure 3. Oxide weight fractions at Hole 752B. 


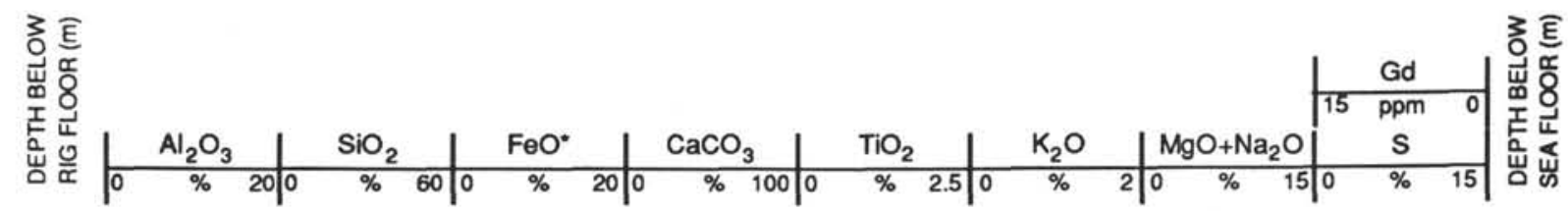

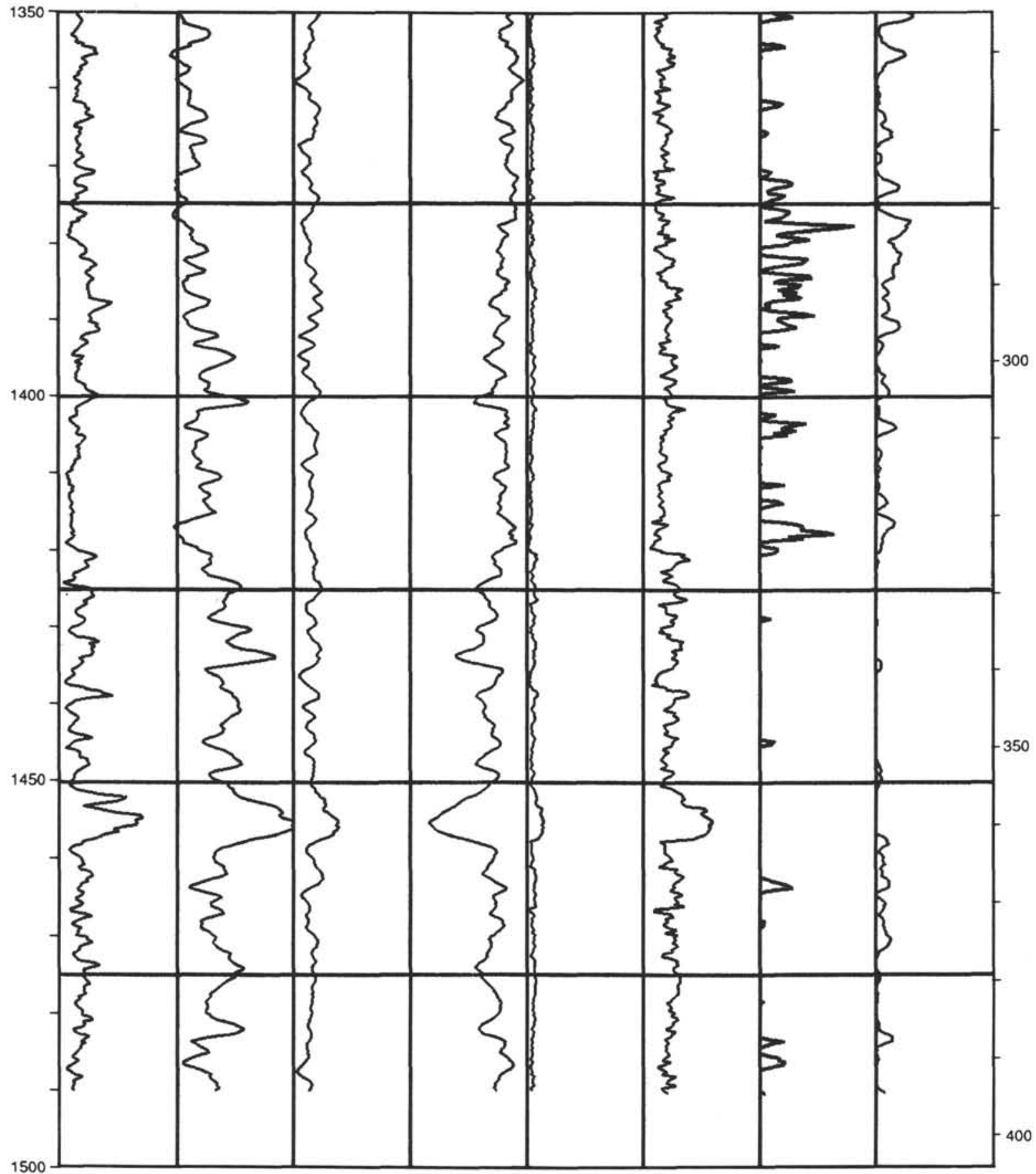

Figure 3 (continued). 

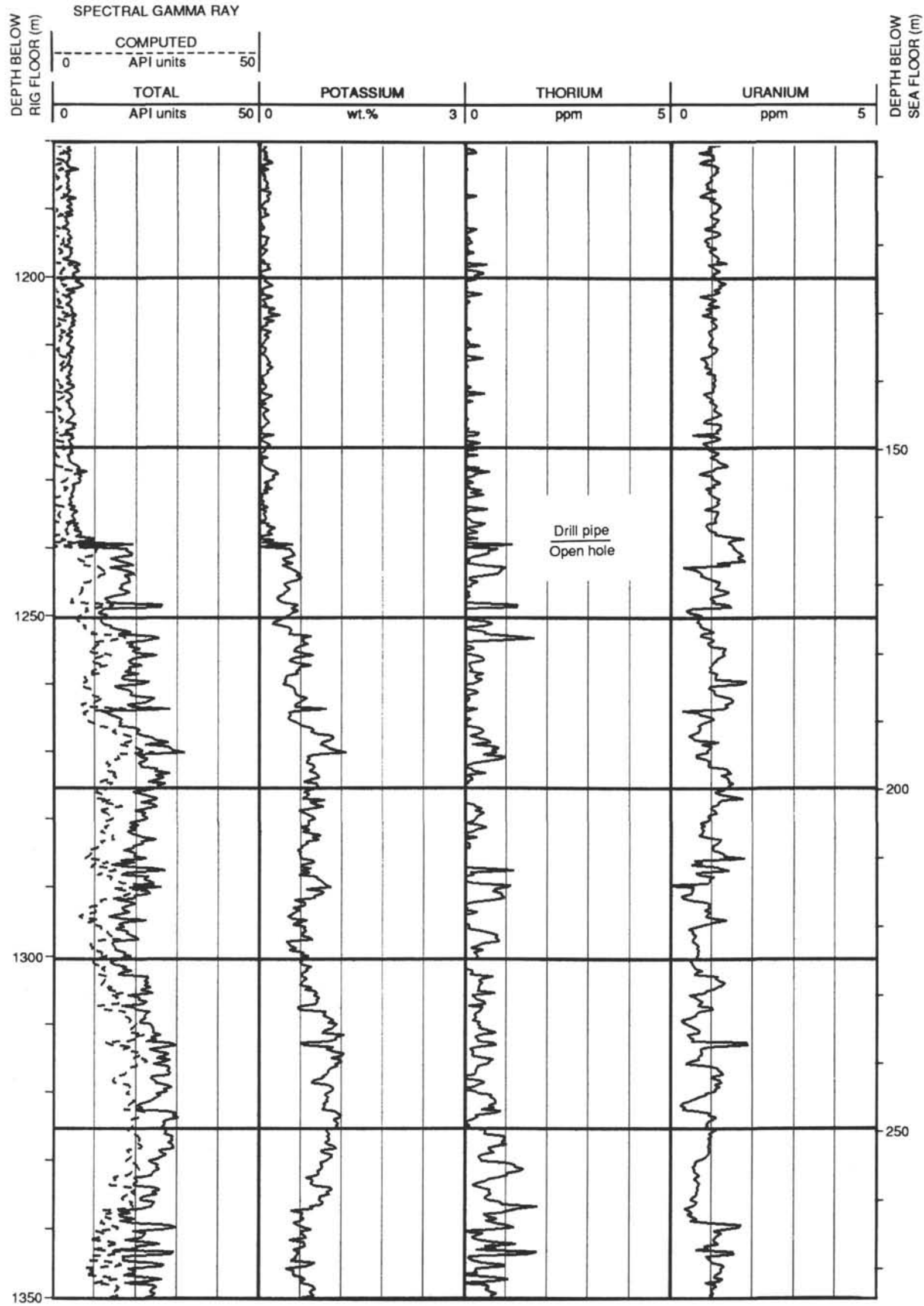

Figure 4. Processed natural gamma-ray curves from Hole 754B. 

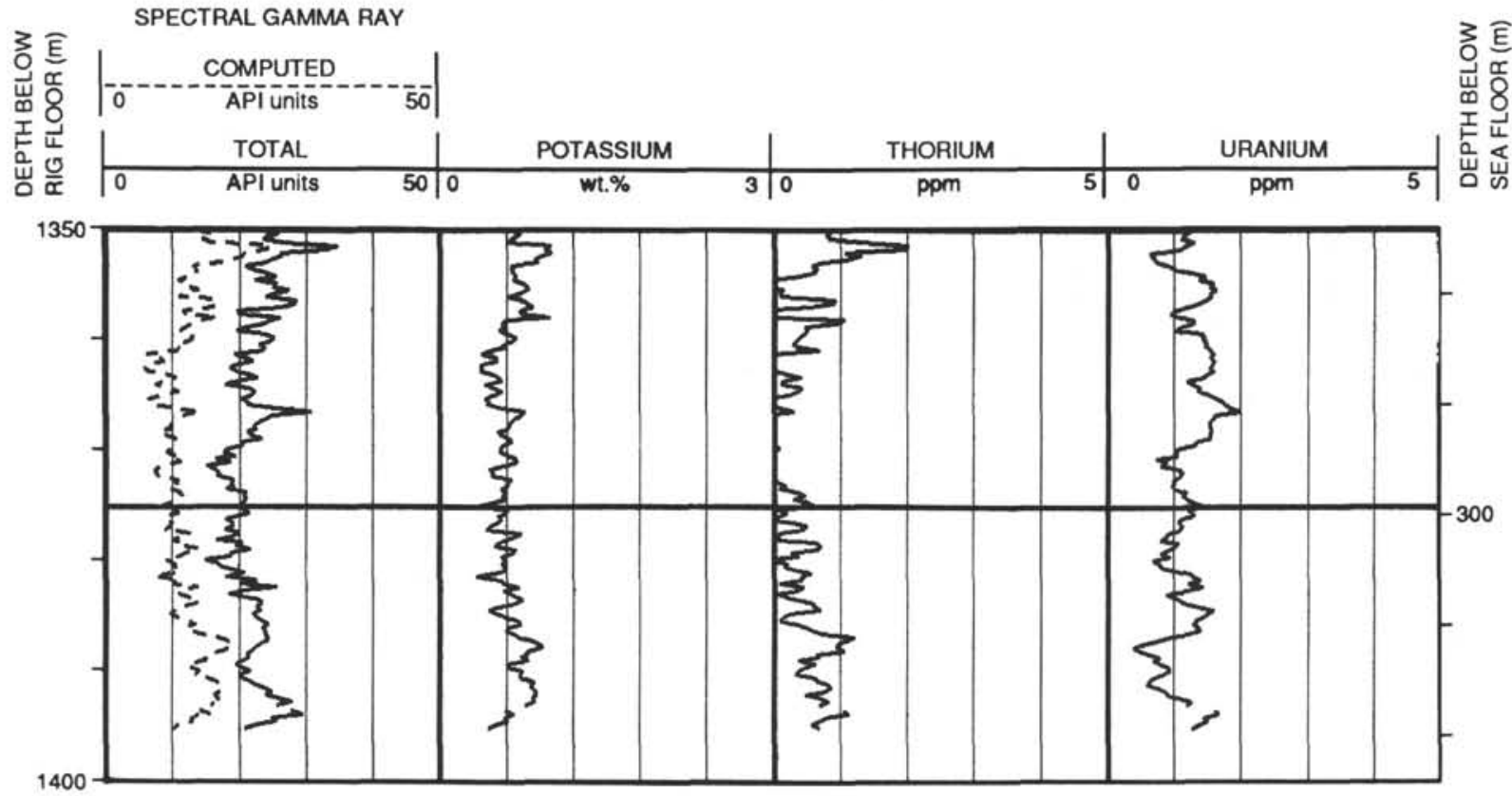

Figure 4 (continued). 


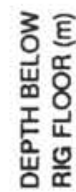
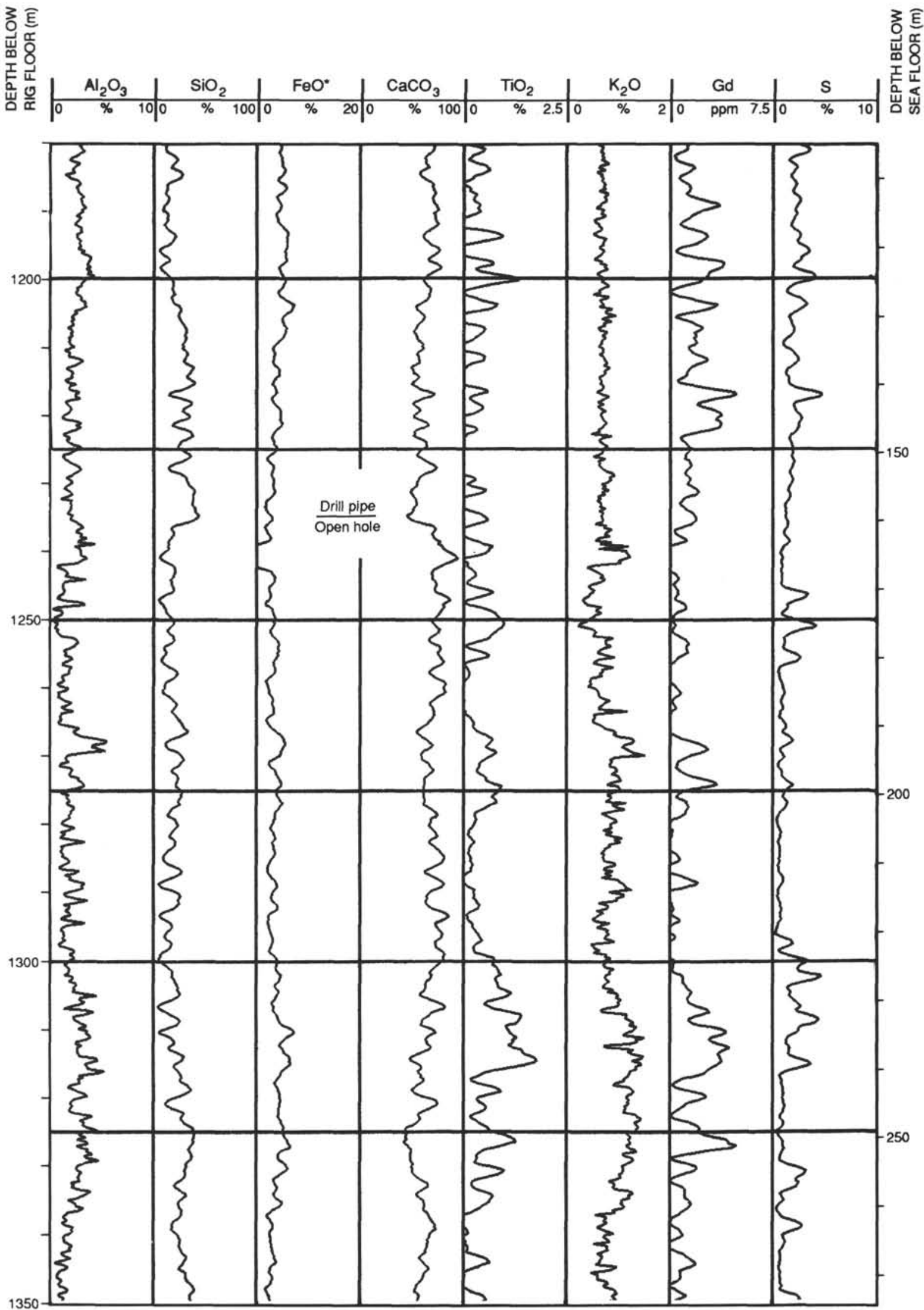

Figure 5. Oxide weight fractions at Hole 754B. 

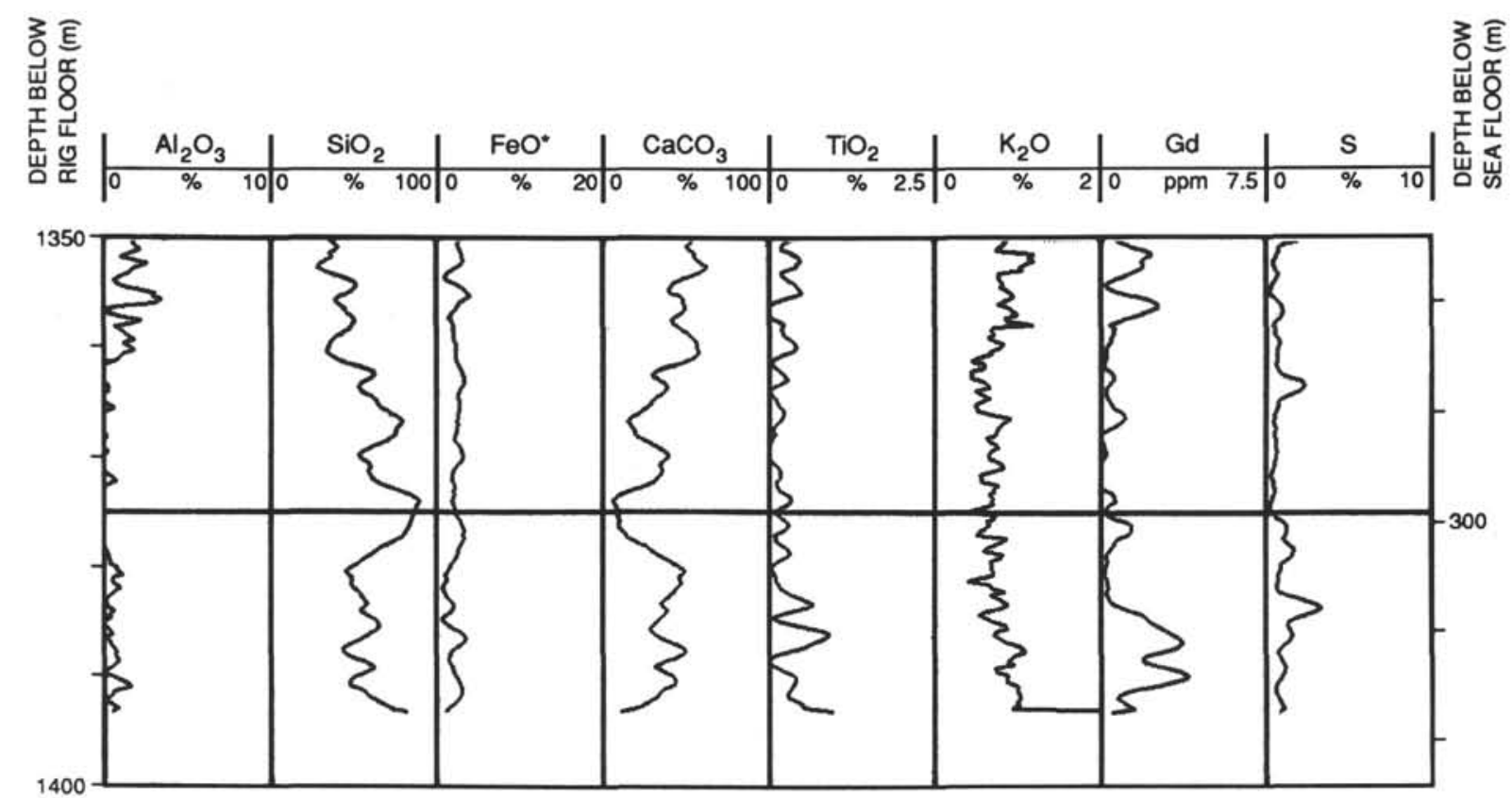

Figure 5 (continued). 

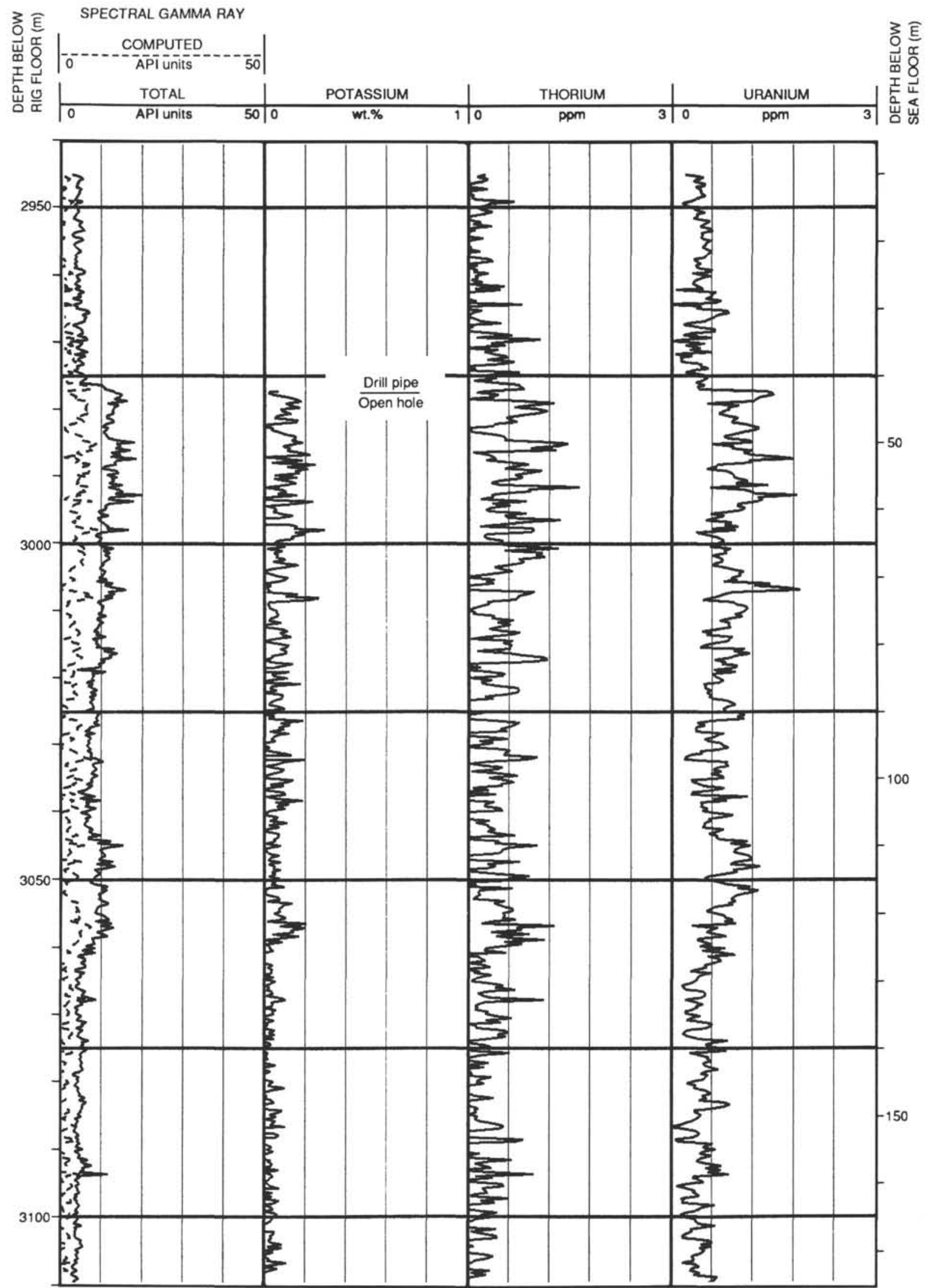

Figure 6. Processed natural gamma-ray curves at Hole 758A. 

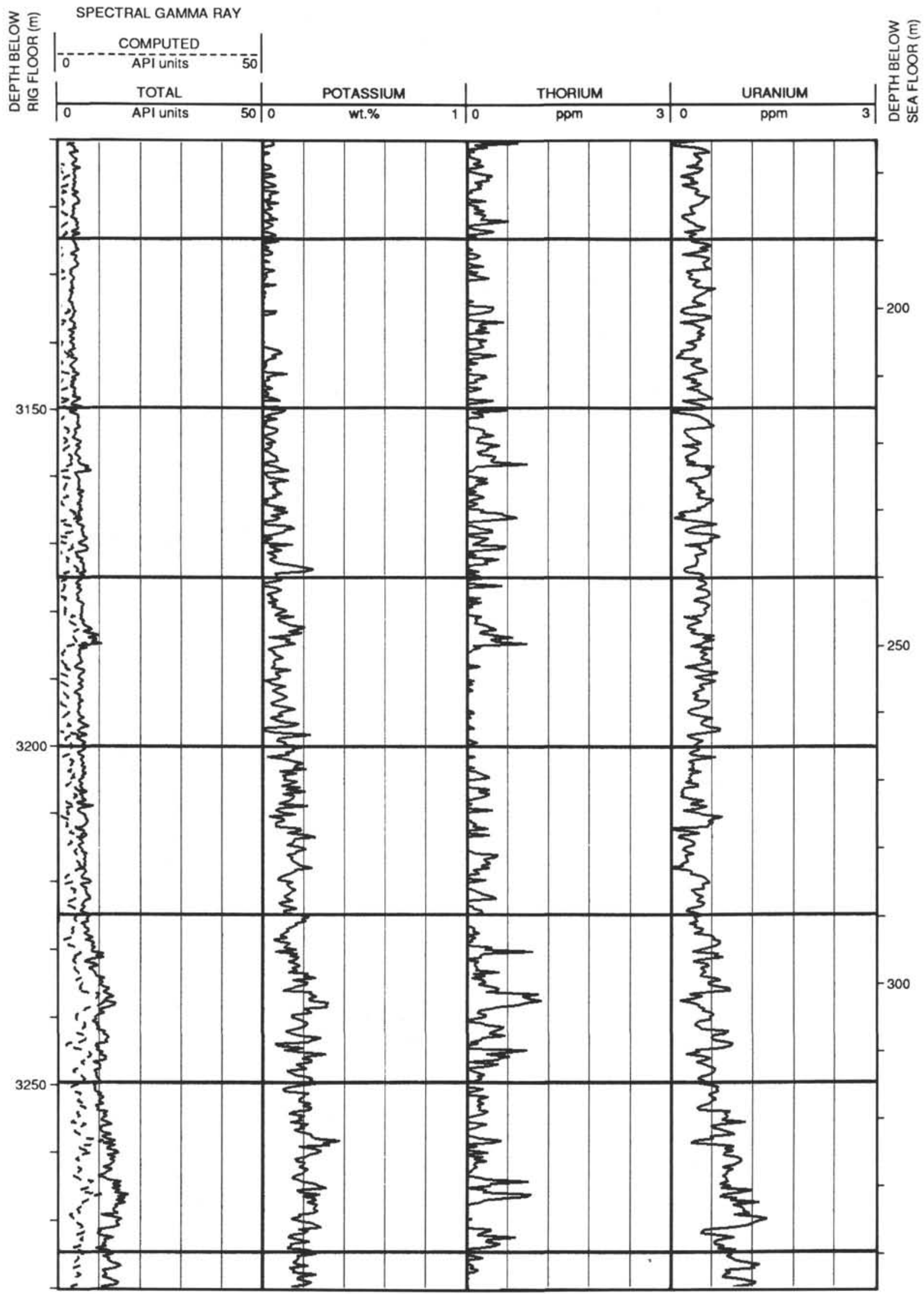

Figure 6 (continued). 

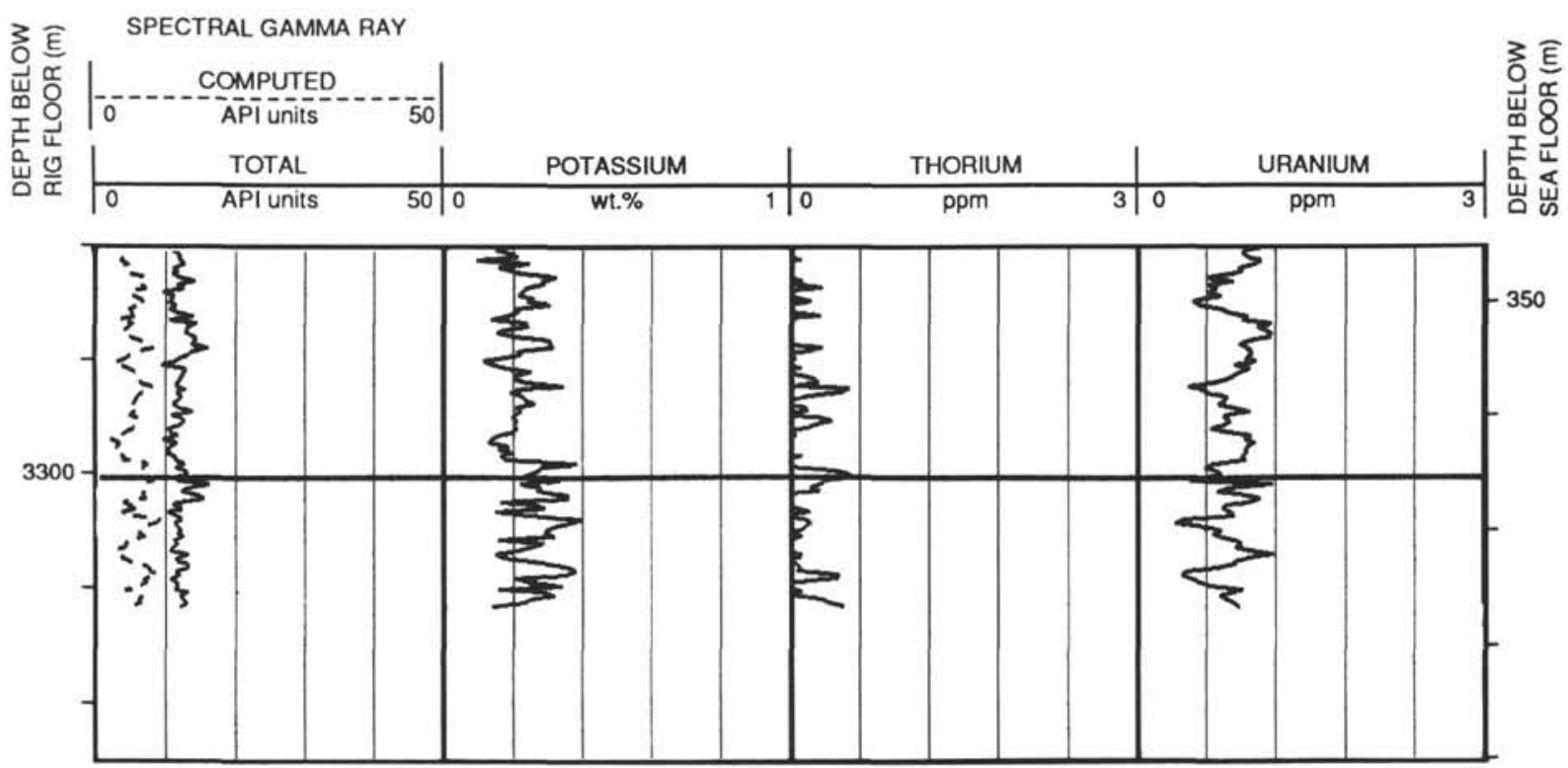

Figure 6 (continued).

\section{COMPARISON OF GEOCHEMICAL WELL LOGS AND CORE-DERIVED LITHOLOGY}

\section{Hole 752B}

The reprocessed natural gamma-ray logs from the geochemical logging run are displayed in Figure 2. The data are corrected for pipe attenuation, borehole size changes, and borehole fluid. Figure 3 displays the computed oxide weight fractions. The section of this well-recorded through-pipe is not displayed, owing to the poor quality of the data; when geochemical logs are recorded in high-porosity sediments through pipe, the signal from the formation is weak because the signal is dominated by the chlorine and hydrogen from the borehole and iron from the pipe. The field tape containing the spectrum recorded in the lower interval (224-395 mbsf) was damaged; therefore, on land the spectral analysis could not be done to include $\mathrm{Ti}, \mathrm{Gd}$, and $\mathrm{K}$ in this interval. A straightline log was created for these three elements using the average values for these yields in the upper zone, where the spectrum data were present. Any character in these curves is due to a redistribution of the potassium yield by the program when forcing the potassium yield from the geochemical spectroscopy tool to equal the potassium from the natural gamma-ray tool. The combination of $\mathrm{MgO}+\mathrm{Na}_{2} \mathrm{O}$ is calculated in this hole using the photoelectric factor.

Prominent ash layers were found in the sediments of this hole (Pierce, Weissel, et al., 1989). A zone of ash can be seen on the natural gamma-ray curves as a large increase in thorium below 352 mbsf (Fig. 2). The $\mathrm{Al}_{2} \mathrm{O}_{3}, \mathrm{SiO}_{2}, \mathrm{FeO}^{*}$, and $\mathrm{K}_{2} \mathrm{O}$ curves are useful clay indicators, which indicate a thin clay layer from 177 to $182 \mathrm{mbsf}$, as well as an overall increase in clay content at 215 mbsf. The carbonate content is high in the upper portion of the well $(85 \%)$, but drops to an average $65 \%$ below 324 mbsf. The Cretaceous/Tertiary boundary at approximately $360 \mathrm{mbsf}$ on the logs is marked by a sharp decrease in $\mathrm{CaCO}_{3}$ and increase in $\mathrm{Al}_{2} \mathrm{O}_{2}, \mathrm{SiO}_{2}, \mathrm{~K}_{2} \mathrm{O}$, and $\mathrm{FeO}^{*}$.

\section{Hole 754B}

The reprocessed gamma-ray curves of Hole 754B are displayed in Figure 4. The data presented here come from the first pass of the geochemical tool string. The data were recorded open-hole except for the upper $58 \mathrm{~m}$, which were recorded through pipe. Attenuation in these curves has not been corrected for due to processing time constraints on land. Figure 5 displays the oxide weight fractions for Hole 754B. Both the potassium curve and iron yield were corrected for pipe effects before oxides were computed. $\mathrm{MgO}+\mathrm{Na}_{2} \mathrm{O}$ were not calculated because of the lack of a PEF measurement.

As in Hole 752B, the well logs of Hole 754B permit the definition of several ash layers. From 263 to $273 \mathrm{mbsf}$, the gamma-ray curves take on a unique comb-like pattern, where each peak couples with high thorium values. The boundary between the limestone lithology of Subunit IIB (190.3-287.0 mbsf) and limestone plus chert lithology of Subunit IIC (287.0-354.7 mbsf) is readily distinguished on the logs by an increase in $\mathrm{SiO}_{2}$ and a decrease in $\mathrm{CaCO}_{3}$ in Subunit IIC. The $\mathrm{K}_{2} \mathrm{O}$ and $\mathrm{Al}_{2} \mathrm{O}_{3}$ curves track each other throughout the hole, and together show a decrease in clay content in Subunit IIC relative to Subunit IIB.

\section{Hole 758B}

The reprocessed natural gamma-ray logs for Hole 758B are displayed in Figure 6. The log data come from the geochemical tool string. Through-pipe attenuation has not been corrected for in the upper $30 \mathrm{~m}$ of log data, due to time constraints. The dry $w t \%$ of the oxides are displayed in Figure 7. Through-pipe logs are not displayed because of poor data from the extremely low signal-to-noise ratio in this portion of the hole. The combined measurement of $\mathrm{MgO}+\mathrm{Na}_{2} \mathrm{O}$ is not calculated because the lithodensity tool was not run in this hole.

The $\mathrm{K}_{2} \mathrm{O}$ and $\mathrm{Al}_{2} \mathrm{O}_{3}$ logs indicate that the chalks described in Unit IIA (121.7-295.6 mbsf) have a lower clay content than the overlying oozes of Unit I (0-96.0 mbsf) and underlying calcareous chalk with clays of Unit IIB (295.6-367.3 mbsf). The volcanic clays of Unit III show an increase in $\mathrm{Al}_{2} \mathrm{O}_{3}, \mathrm{SiO}_{2}, \mathrm{FeO}^{*}, \mathrm{TiO}_{2}$, and a decrease in $\mathrm{CaCO}_{3}$.

\section{CONCLUSION}

The natural gamma-ray field logs have been reprocessed and combined with the gamma-ray spectrometry data to obtain quantitative measurements of the oxides at Sites 752, 754, and 758. The geochemical logs are useful in distinguishing the major lithologic changes in each well and have been used to calculate a 
representative lithologic column and to interpret the geology where core data were missing (Littke et al., this volume).

\section{ACKNOWLEDGMENT}

A special appreciation is expressed to Jennifer Tivy, who edited the paper and provided very helpful suggestions.

\section{REFERENCES}

Hertzog, R., Colson, L., Seeman, B., O'Brien, M., Scott, H., McKeon, D., Wraight, P., Grau, J., Schweitzer, J., and Herron, M., 1987. Geochemical Logging With Spectrometry Tools: Soc. Pet. Eng. Pap., 18:792.
Lock, G. A., and Hoyer, W. A., 1971. Natural gamma-ray spectral logging. Log Analyst, 12:3-9.

Peirce, J., Weissel, J., et al., 1989. Proc. ODP, Init. Repts., 121: College Station, TX (Ocean Drilling Program).

Ruckenbusch, G., 1983. A Kalman filtering approach to natural gammaray spectroscopy in well logging. IEEE Trans. Automatic Control, 28:372-380.

Scott, H. D., and Smith, M. P., 1973. The aluminum activation log. Log Analyst, 14:3-12.

Date of initial receipt: 7 March 1990 Date of acceptance: 10 October 1990 Ms 121B-155 
勇
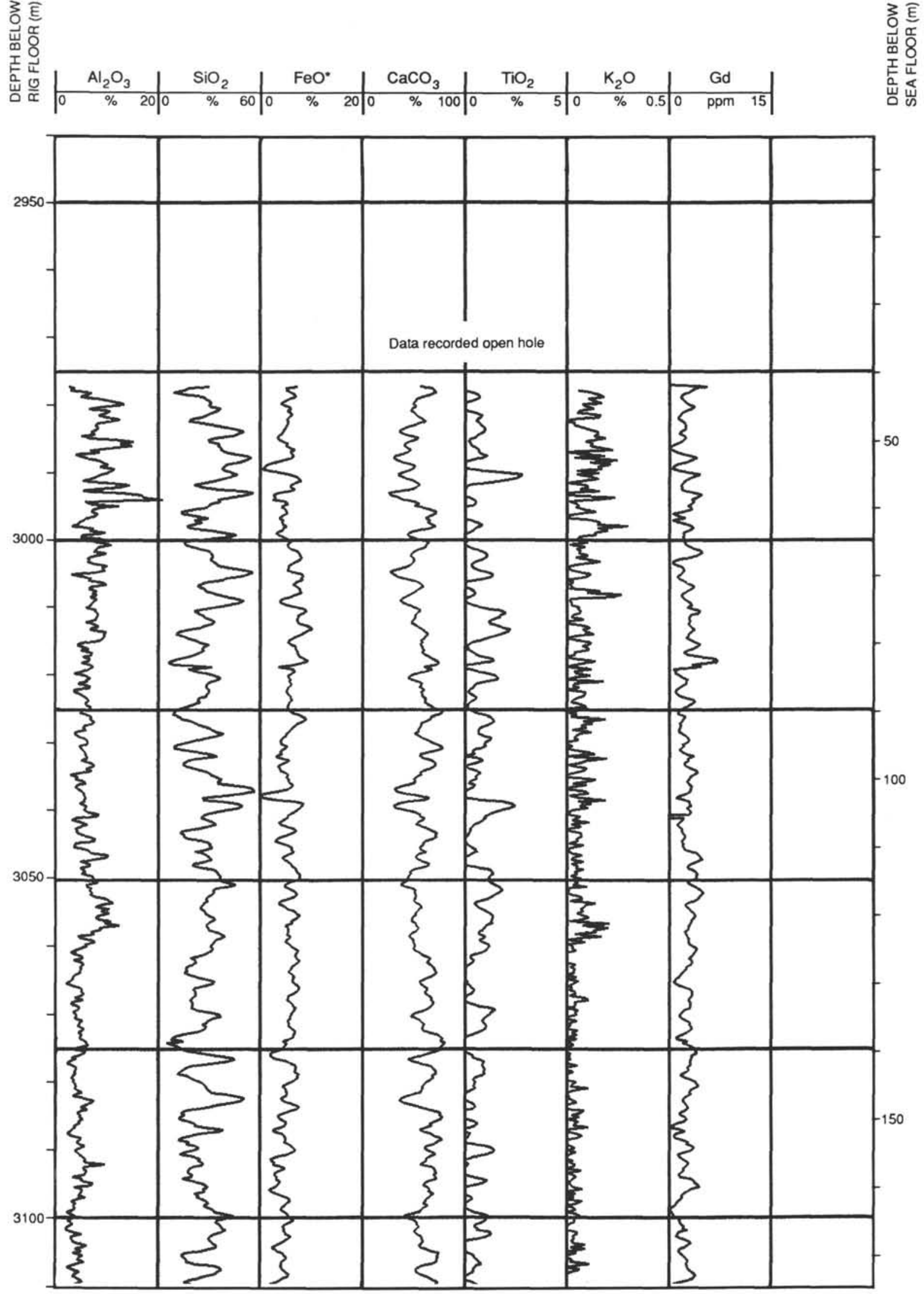

Figure 7. Oxide weight fractions and gadolinium at Hole 758A. 

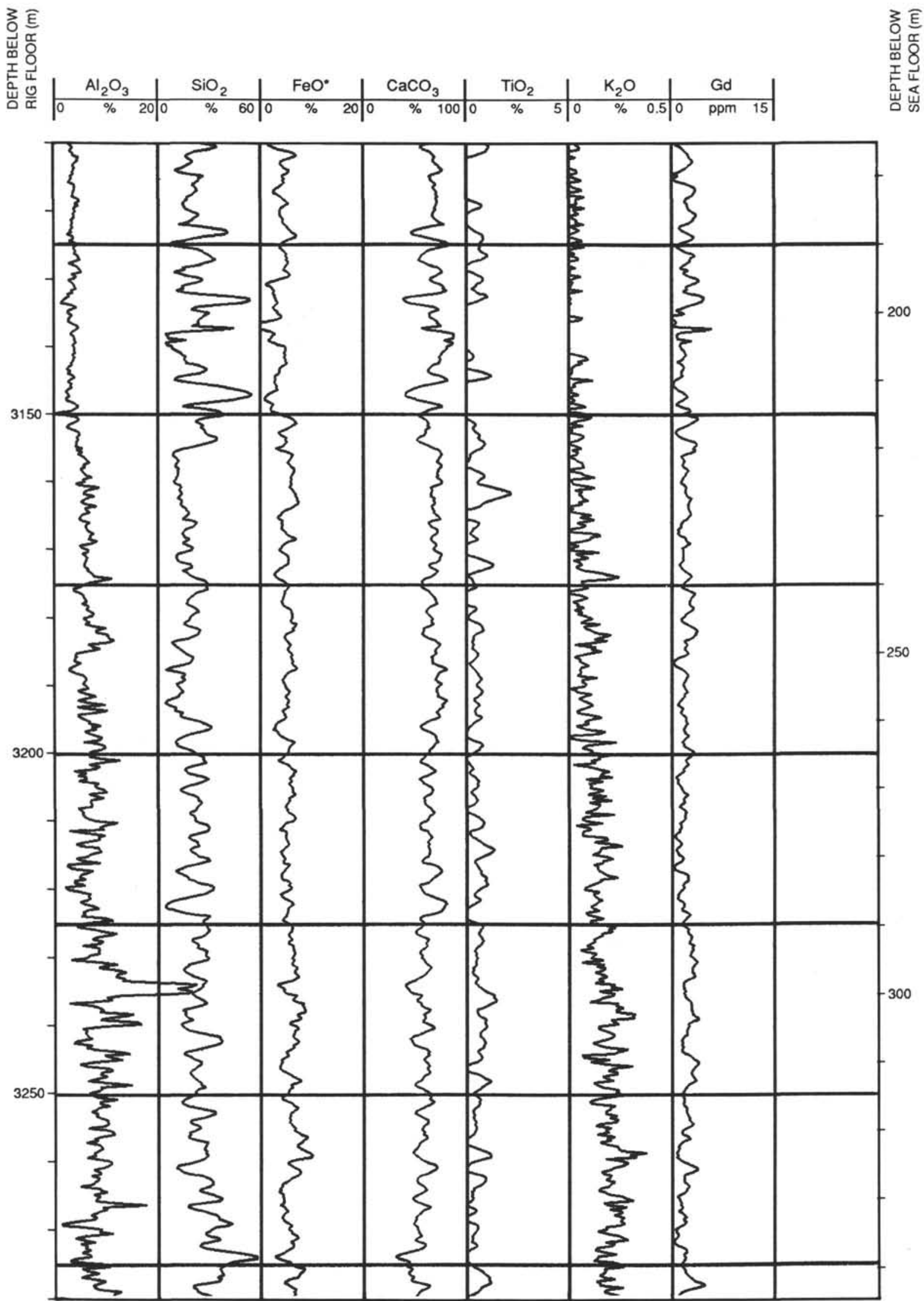

Figure 7 (continued). 


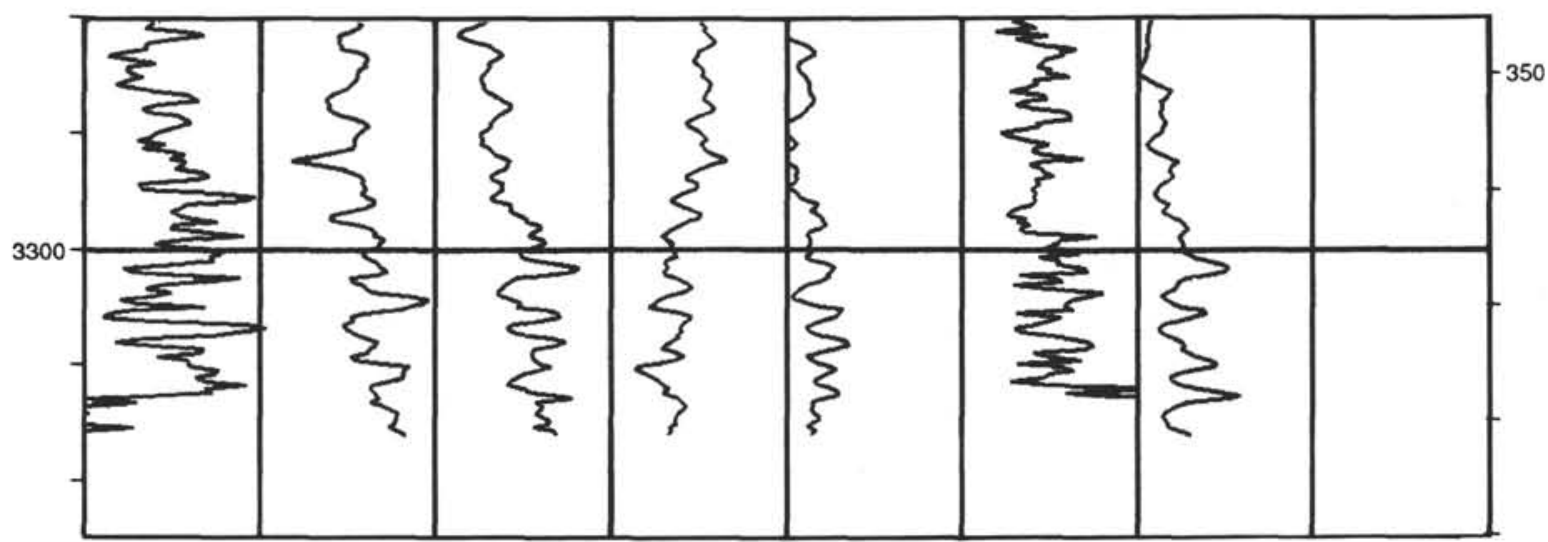

Figure 7 (continued). 